\title{
Fotovoltaik Panellerde Verim İyileştirme Yöntemleri
}

\author{
1* Hakan Karakaya and ${ }^{2}$ İzzettin Enes Şen \\ 1*Batman University Eng.-Arc. Fac. Mechanical Engineering Department hakan.karakaya@batman.edu.tr \\ ${ }^{2}$ Batman University Eng.-Arc. Fac. Mechanical Engineering Department ienessen@gmail.com
}

\begin{abstract}
Özet
Günümüzde artan nüfus miktarl beraberinde sanayileşme kentleșme ve beraberinde enerjiye olan talebi artırmıştır. Fosil yakıtların yanı sıra kullanılan temiz sürdürülebilir enerji kaynakları arasında yenilenebilir enerji kaynă̆l olan güneş enerjisinin önemi git gite artmaktadır. Güneş enerjisiden elektrik enerjisi üretmenin yollarından bir tanesi fotovoltaik panel kullanımıdır. Elektrik enerjisi üretiminde günümüzde maksimum \%24 değerlerinde bir verimle güneşten gelen radyasyonun bir kısmını elektrik enerjisine çevrilebilir. Kullanılan bu enerjinin verimli olması yapılan yatırım ve geri dönüş için önem arz etmektedir. Araştırmacılar tarafindan panel verimliliğinin artırılması için yüzey soğutma, yarı iletken malzeme değiştirilmesi, optimum açı yakalama, güneş takip sistemleri vb. çalışmalar yapılmıştır. Yapılan bu çalışmalar sonucunda fotovoltaik panellere göre \%47'e kadar verim artışı sağlanmıştır. Fakat verim artışının yanında maliyet artışı irdelenmesi önem arz etmektedir.
\end{abstract}

Anahtar Kelimeler: Güneş enerjisi, Fotovoltaik panel, verim

\section{Giriş}

Günümüzde enerji üretimi açısından petrol kömür doğalgaz gibi fosil yakıtlar kullanılmaktadır. Fosil yakıtların sınırlı olması ve çevreye duyarlı olmaması sebebiyle güneş, rüzgar, biyokütle vb. temiz, çevreci ve sürdürülebilir enerji kaynaklarının kullanımı artış göstermiştir. Yenilenebilir enerji kaynakları içerisinde yer alan güneş, en çok kullanılan sürdürülebilir kaynaklar arasında yer almaktadır. Güneș enerjisinden elektrik enerjisi elde etme yöntemi isıl ve fotovoltaik olmak üzere ikiye ayrılır. Isıl enerji olarak güneşten gelen radyasyon bir merkezi alıcıda toplanarak yüksek 1s1 elde edilir ve sonrasında bu 1sı ile kızgın buhar oluşturularak türbin çevrilir ve hareket enerjisi motora aktarılarak enerji üretimi gerçekleşir. Fotovoltaik hücrelerde ise, $\mathrm{n}$ ve $\mathrm{p}$ tipi yarı iletken malzeme kullanarak güneșten gelen radyasyon elektron hareketliliğine sebep olur ve hareket eden elektronlardan elektrik enerjisi elde etmiş oluruz. Günümüzde fotovoltaik panellerden elde edilen verimleri \%17.4-24civarındadır[1]. Enerjinin üretilmesinin yanı sıra verimli olması da önemlidir. Fotovoltaik panellerde üretimin daha verimli hale getirilmesi konusunda araştırmacılar tarafından birçok çalışma yapılmıştır.

Zhijun ve arkadaşları Birleşik Krallıkta yapmış oldukları çalışmada 2 adet fotovoltaik panel üzerinde su ile soğutma yaparak verim artışı olup olmadığını incelemişlerdir. Yapmış oldukları çalışmalar sonucunda bir panelin su ile soğutulup diğer panelin su ile soğutulmaması sonucunda akım ve gerilim değerlerinde değişmeler görüp verim artışında $\% 47$ gibi bir oran elde

*Corresponding author: Address: Eng.-Arc. Fac. Mechanical Engineering Department Batman University, 72060, Batman TURKEY. E-mail address: hakan.karakaya@batman.edu.tr, Phone: +904882174115 
etmişlerdir[2].

Mazon ve arkadaşları İspanyada Politeknik Üniversitesinde yapmış oldukları çalışmada iki adet fotovoltaik panel kullanarak hava ile soğutma yapmışlardır. İlk önce doğal taşınım ile sonrasında zorlanmış taşınım ile panel soğutulmuştur. Deneysel çalışmalar sonucu zorlanmış taşınım doğal taşınıma göre \%3-5 arasında daha fazla verim artışı görülmüştür[3].

Arslan ve Kurukavak, Karabük'te yapmış oldukları çalışmada 1 adet güneş panelini saf su ile diğerini nano parçacık içeren saf su ile soğutmuşlardır. Deneyler sonucunda debileri sırasıyla $0,020 \mathrm{~kg} / \mathrm{s}, 0,033 \mathrm{~kg} / \mathrm{s}, 0,051 \mathrm{~kg} / \mathrm{s}$ ve $0,063 \mathrm{~kg} / \mathrm{s}$ değerlerinde alındığında, ortalama kolektör verimleri sırasıyla nano akışkan için $\% 50,45, \% 52,74, \% 59,16$ ve \%56,61; herhangi bir nano parçacık içermeyen saf su için \%36,51, \%38,83, \%43,53 ve \%41,17 olarak hesaplamıştır[4].

Bonkaney ve arkadaşları Nijer'de yapmış oldukları çalışmada $25 \mathrm{~W}$ bir güneş paneli kullanarak 4 ay boyunca bulutlu günlerde elde edilen elektriksel enerjinin ortalamasını alarak maksimum verime oranla \%25 kayıp elde edilmiştir. Ayrıca yapmış oldukları çalışmada haziran ayında 23 gün boyunca 2 adet fotovoltaik panelin biri temizlenip diğeri temizlenmemiştir. Deney sonucunda elektriksel güç değerinde \%10 değerinde bir düşüş meydana gelmiştir[6].

Kamanga ve arkadaşları Malavi'de yapmış oldukları çalışmada piranometre kullanarak 0, 15, 20 ve 25 derece açıyla yerleştirip günlük 1şınım değerlerini incelemişlerdir. Sonuç olarak panellerin güney yönünde 25 derece açıyla yerleştirildiğinde en yüksek 1şınım değerini elde edeceği sonucuna varmışlardır. Ek olarak şekilde 0 ile 25 derece açlların saat 12 civarında değerleri karşılaştırıldığında \%20 verim artışı elde etmişlerdir[3].

Lazaraiu ve arkadaşları Romanya'da 142,4 W gücünde 2 adet fotovoltaik panel kullanarak birini takip sistemli birini iste sabit gözlemlemişlerdir. Deneysel çalışmalar sonucunda sistemin sabit eksenli sisteme göre \%12ile \%20 arası bir verim artışı olduğunu göstermişlerdir[11]. 


\section{Fotovoltaik panelden elektrik üretimi}

Fotovoltaik panel yüzeyinde bulunan $3 \mathrm{~A}$ ve $5 \mathrm{~A}$ grubu olan $\mathrm{n}$ ve $\mathrm{p}$ tipi yarı iletkenler sayesinde üzerinde düssen güneş 1şınlarından dolayı bir elektron hareketi olur. Elektronların yer değiştirmesiyle bir yarı iletkenden elektron koparılır ve diğerinin valans elektron yörüngesini doldurur. Bu işlem güneş 1şınları panel yüzeyine geldikçe ve gölgelenme olmadığı sürece gerçekleşir. Şekil 2.1 de görüldüğü gibi oluşan elektron hareketliliğinden ötürü elektrik enerjisi üretimi gerçekleşir[5].

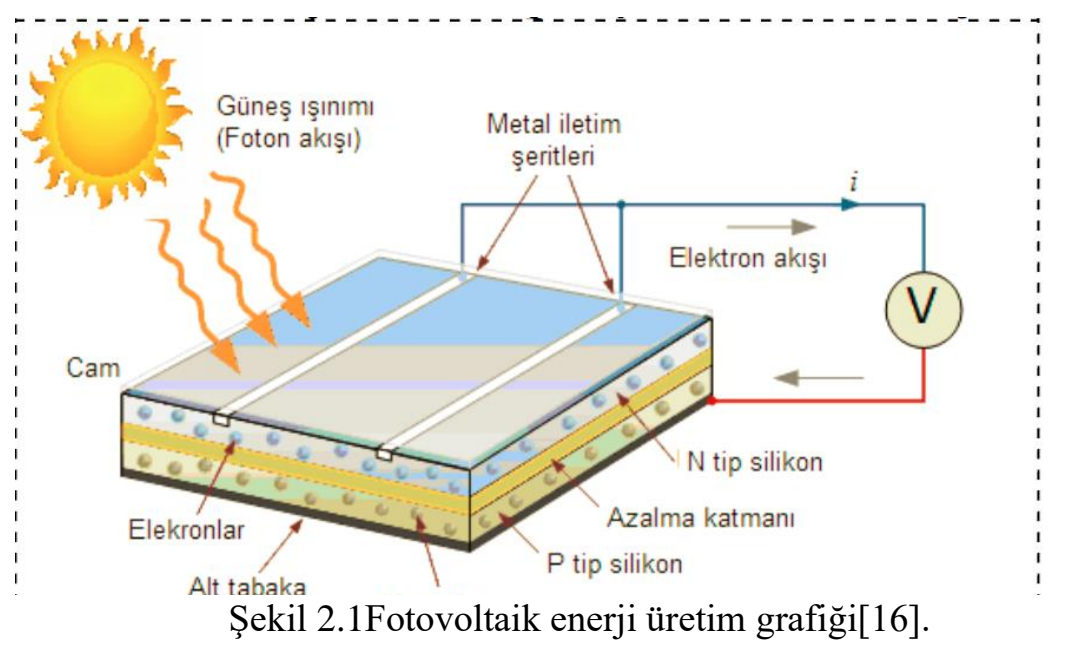

\section{PV Panelde verim iyileştirme metotları}

Fotovoltaik paneller güneş 1şı̆̆ına direk maruz kalarak elektrik enerjisi elde edebilen cihazlardır. Doğrudan güneş 1şığına maruz kalmaları sebebiyle panel üzerinde oluşan 1sı miktarı artmakta ve verim kaybına yola açmaktadır. Bundan ötürü verim artırmak için çeşitli yollara başvurulmaktadır. Verim, sistemden çıkan enerjinin sisteme giren enerjiye oranıdır ve termodinamik kanunları gereği birden küçük bir değerdir. Verim daha çok \% olarak ifade edilir. Fotovoltaik panel verimi hesaplanırken altta görüldüğü gibi panelden elde ettiğimiz maksimum verim güneşten gelen radyasyon değerine ve yüzey alanına bölündükten sonra 100 ile çarpılarak elde edilen değerdir [17].

$$
\eta_{\max }=\frac{P_{\max }}{\mathrm{E} * A_{c}} \times 100 \%
$$


Fotovoltaik panellerde verim iyileştirme yöntemleri yüzey soğutma, yarı iletken malzemenin iyileştirilmesi ve diğer faktörler olarak 3 ana başlıkta incelenebilir. Yapılan çalışmalar konular üzerine odaklanmıştır[9].

\subsection{Yüzey soğutma}

Güneş panellerinin en iyi çalışma sıcakları 25 derecede gerçekleşmektedir. Yüzeyde meydana gelen artışlar 40 ile 45 dereceyi aştığında verimde ciddi azalmalar meydana gelmektedir. Oluşan kayıpların önlenmesi adına panel altından bir akışkan gezdirerek veya faz değiştiren malzeme konarak yüzeyde oluşan ısıyı akışkana veya faz değiştiren malzemeye transfer edip yüzeye sıcaklığında düşüş oluşturarak verim artırılır [7].

\subsubsection{Su ile soğutma}

Panel altına su konarak veya su gezdirilerek panel yüzeyinde oluşan ısıyı suya aktararak yüzey sıcaklığında azalma gözlenir. Zhijun ve arkadaşları Birleşik Krallıkta yapmış oldukları çalışmada 2 adet fotovoltaik paneli kullanıp birini su soğutarak diğerini ise sadece kıyaslama yaparak incelemişlerdir. Deney sonucu Şekil 3.1 de görüldüğü üzere \%47 verim elde edilmiştir[2].

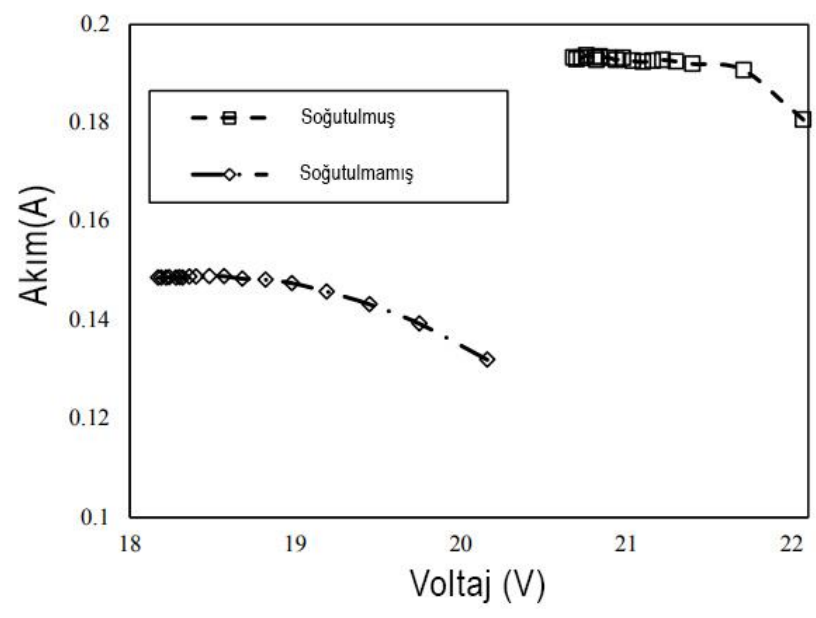

Şekil Hata! Belgede belirtilen stilde metne rastlanmadı..1 Voltaj akım ilişkisi[2]

\subsubsection{Hava ile soğutma}

Panel hava sirkülasyonunun fazla olduğu bölgelere yerleştirilerek yüzeyde oluşan sıcaklık, rüzgar sayesinde doğal taşınım olarak düşürülür. Zorlanmış taşınım olarak harici bir pervane eklenerek panel üzerindeki sıcaklık azaltılır. Mazonve arkadaşları İspanyada Politeknik Üniversitesinde yapmış oldukları çalışmada iki adet güneş paneli kullanarak ilk önce doğal taşınım ile sonrasında zorlanmış taşınım ile güneş paneli soğutulmuştur. Şekil 3.2 incelendiğinde zorlanmış taşınım doğal taşınıma göre \%3-5 arasında daha fazla verim artışı görülmüştür[3]. 


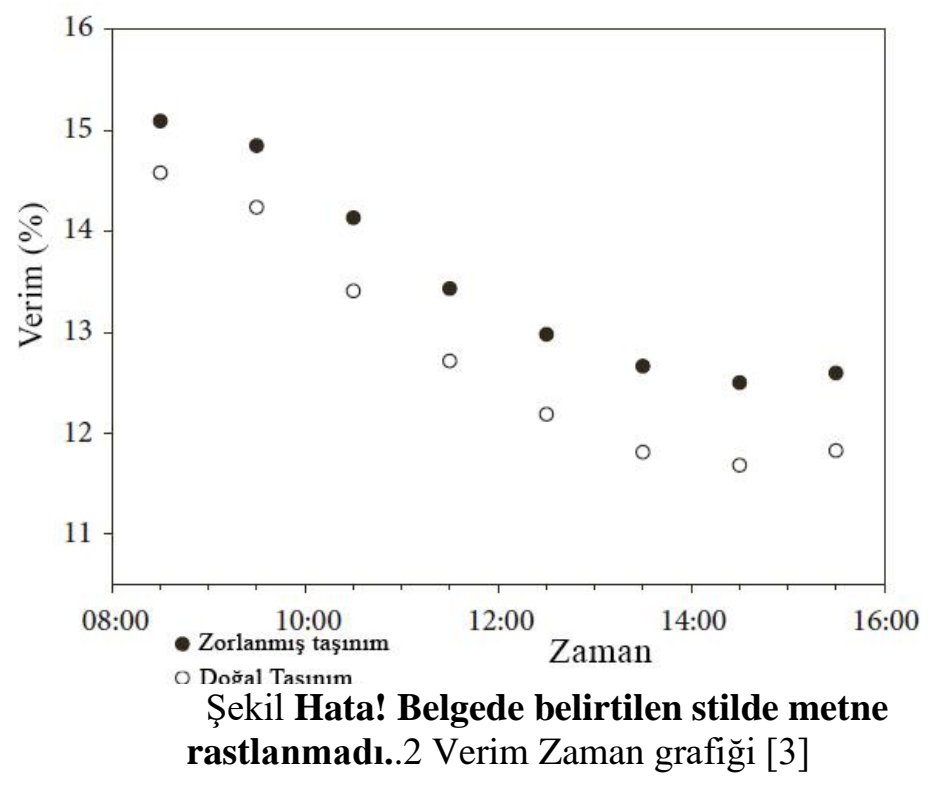

\subsubsection{Nano akışkan ile soğutma}

Nano akışkan çapları 1 ile $100 \mathrm{~nm}$ arasında değişen akışkan içerisine girip 1sı transferini ve termal performansı artıran malzemedir. Akışkan ile soğutulan fotovoltaik panelin içerisinde konan bu akışkan ile verim artışı sağlanmaktadır[10].Arslan ve Kurukavak, yapmış oldukları çalışmada 1 adet güneş panelini saf su ile diğerini nano parçacık içeren saf su ile soğutmuşlardır. Deneyler sonucunda debileri sirasiyla $0,020 \mathrm{~kg} / \mathrm{s}, 0,033 \mathrm{~kg} / \mathrm{s}, 0,051 \mathrm{~kg} / \mathrm{s}$ ve $0,063 \mathrm{~kg} / \mathrm{s}$ değerlerinde alındı ̆̆ında, ortalama kolektör verimleri sırasıyla nanoakışkan için \%50,45, \%52,74, $\% 59,16$ ve $\% 56,61$; herhangi bir nanoparçacık içermeyen saf su için $\% 36,51, \% 38,83, \% 43,53$ ve $\% 41,17$ olarak hesaplamıştır[4].

\subsubsection{Faz değiştiren malzeme ile soğutma}

Fotovoltaik panelin alt kısmına yerleştirilen faz değiştiren malzeme bölgeye göre değişen erime sıcaklığına ulaştığında yüzeydeki sıcaklığ1 gizli 1sı olarak depo edip paneli soğutup verim artış1 sağlar.Stropnik ve Stritih, yapmış oldukları çalışmada fotovoltaik paneli faz değiştiren malzeme kullanarak soğutmuşlardır. Deneysel çalışmalar sonucu ortalama olarak \%1.1 ile \%2.8 arasında verim artışı elde etmişlerdir. Ek olarak yıllık elektrik üretiminde kıyasladıkları soğutmasız fotovoltaik panele göre ortalama $\% 7.3$ daha fazla üretim gerçekleştiğini elde etmişlerdir[15].

\subsection{Yart iletken malzeme iyileştirilmesi}

Üretilen hücre çeşidine göre fotovoltaik panellerde verim artışı görülmektedir. 


\subsubsection{Monokristal hücre}

Monokristal silikon hücre üretiminde 'Czochralsi Metodu' kullanılmaktadır. Bu yöntemde silisyum dioksit bir kaba konarak yüsek sıcaklıkta eritilir sonrasında küçük bir parça kristal eriyik halde bulunan malzemenin içine daldırılarak yavaş yavaş yukarı doğru soğuyan bölgeye çekilerek üretimi gerçekleştirilir. Üretilmiş malzeme $0.2 \mathrm{~mm}$ kalınlıklarında kesilerek hücre yapımı gerçekleştirilir. Genellikle koyu mavi-siyah renktedir. En yüksek verimlilikleri \%24 olarak bilinmektedir[1].

\subsubsection{Polikristal hücre}

Polikristal hücre üretimi monokristal hücre üretimine benzer şekilde gerçekleşmektedir. Polikristal hücre eriyik halde iken soğutma kaplarında soğutulur. $0.2 \mathrm{~mm}$ kalınlıklarda dilimlenerek yarı iletken malzemelerin bir araya gelmesi ile oluşturulur. Açık mavi görünümleri vardır. En yüksek verimlikleri \%17.4 olarak bilinmektedir[1].

\subsubsection{Bakır indiyum galyum selenit hücre}

Bakır indiyum galyum ve selenit elementlerinden oluşmuş ince yapıda esnek bir fotovoltaik paneldir[14]. Verimlilikleri \%15.2 ile \%22.8 arasında değişkenlik göstermektedir[12,13].

\subsection{Diğer faktörler}

Fotovoltaik panellerin verimliliği etkileyen diğer faktörler gölgelenme, tozlanma, optimum açının belirlenmesi, güneş takip sistemi ve çalışma sıcaklığı olarak 5 farklı kategoride incelenebilir.

\subsubsection{Gölgelenme faktörü}

Güneş paneli üzerine güneş 1şığı aldığı sürece elektrik enerjisi üretebilir. Gölgelenme durumunda da üretim gerçekleşebilir fakat verim ciddi anlamda düşmektedir. Bu açıdan verimli bir sistem için gölgelenme önemli bir rol oynamaktadır. Bonkaney ve arkadaşları Nijer'de yapmış oldukları çalışmada $25 \mathrm{~W}$ bir güneş paneli kullanarak 4 ay boyunca bulutlu günlerde elde edilen elektriksel enerjinin ortalamasını alarak maksimum verime oranla \%25 kayıp elde edilmiştir[6].

\subsubsection{Tozlanma}

Fotovoltaik panellerde gölgelenme önemli bir rol almaktadır. Tozlu bölgelerde özellikle bu konu ciddi önem arz etmektedir. Güneş panelinin yüzeyinde bulunan cam kısmının tozlanması sonucu hücreler yeterince güneş 1şı̆̆ına maruz kalamaz ve bu sebepten ötürü verimliliklerinde azalma meydana gelir. Bonkaney ve arkadaşları Nijer'de yapmış oldukları çalışmada haziran ayında 23 gün boyunca 2 adet fotovoltaik panelin biri temizlenip diğeri temizlenmemiştir. Şekil 3.3'te görüldüğü üzere deney sonucunda elektriksel güç değerinde \%10 değerinde bir düşüş meydana gelmiştir[6].

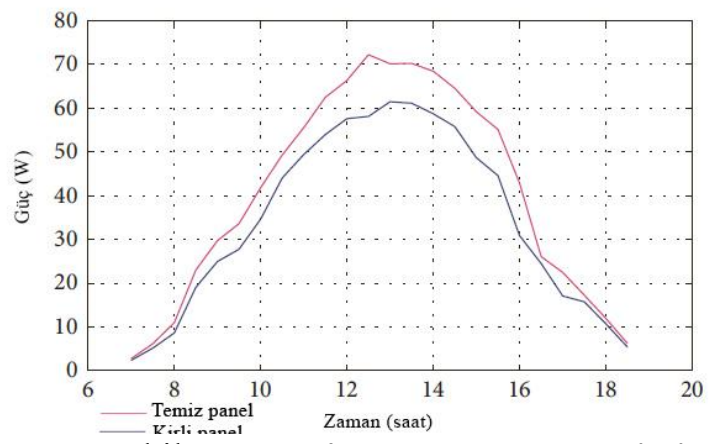

Şekil Hata! Belgede belirtilen stilde metne

rastlanmadı..3Zamana bağlı güç grafiği [6] 


\subsubsection{Optimum açı}

Fotovoltaik panellerin elektrik üretiminde güneş ışığının açısına bağlı olarak verim de değişmeler meydana gelmektedir. Sistemin üzerine gelen güneş 1şılları dik olduğu zaman maksimum verim elde edilir. Kamanga ve arkadaşları Malavi'de yapmış oldukları çalışmada piranometre kullanarak $0,15,20$ ve 25 derece açıyla yerleştirip günlük ışınım değerlerini incelemişlerdir (Şekil 3.4). Sonuç olarak panellerin, güney yönünde 25 derece açıyla yerleştirildiğinde en yüksek 1şınım değerini elde edeceği sonucuna varmışlardır. Ek olarak şekilde 0 ile 25 derece açıların saat 12 civarında değerleri karşılaştırıldığında \%20 verim artışı elde etmişlerdir[3].

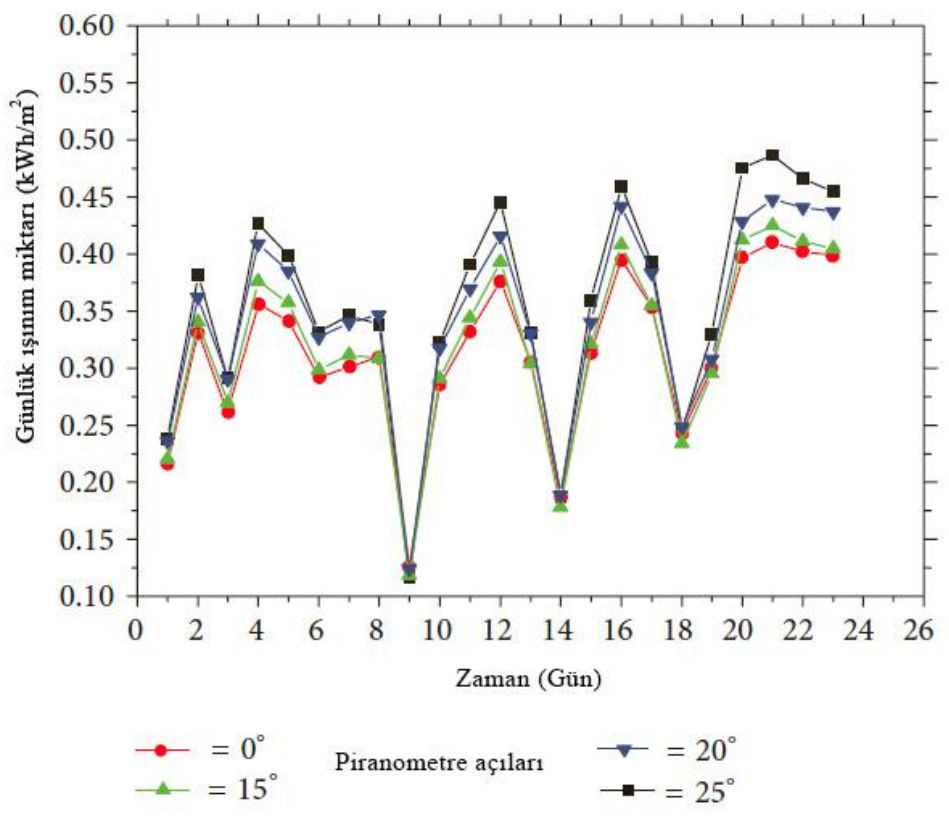

Şekil Hata! Belgede belirtilen stilde metne rastlanmadı..4

Zamana bağlı ışınım grafiği[3]

\subsubsection{Güneş $t$,}

Fotovoltaik panellerin verimlerinin güneş ışınlarının yüzeye dik gelmesi ile birlikte artış sağlandığı bilinmektedir. Fakat panel optimum bir açıla yerleştirilmesine rağmen güneşin doğuş ve batışı esnasında yüzeye dik açıyla gelmeyeceği için güneş takip sistemi kullanılması verimi kayda değer bir şekilde artıracaktır. Lazoraiu ve arkadaşları 142,4 W gücünde 2 adet fotovoltaik panel kullanarak birini takip sistemli birini iste sabit gözlemlemişlerdir. Deneysel çalışmalar sonucunda sistemin sabit eksenli sisteme göre $\% 12$ ile $\% 20$ arası bir verim artışı olduğunu göstermişlerdir[11].

\subsection{5. Çalışma sıcaklı̆g}

Fotovoltaik panellerin maksimum olarak \%24 verimle çalıştı̆̆ bilinmektedir. Ülkemizde kullanılan güneş enerji santrallerinde monokristal ve polikristal hücreler kullanıldığından bu oran $\% 20$ lerin altındadır. Yani güneşten gelen radyasyonun \%80 den fazlas1 elektriksel enerjiye çevrilememektedir. 
Buna ek olarak her $1 \mathrm{C}$ sıcaklık farkında enerjide dönüşümünde \%0.4-0.5 arasında kayıp olmaktadır[9]. Sonuç olarak sıcaklığın verim ile ilişkisi panel verimliliği açısından önemlidir.

\section{Sonuç}

Fosil yakıtların tükenmesi, çevre kirliliğine sebebiyet vermesi ve sürdürülebilir olmaması bizi güvenli ve sınırsız kaynaklar olan yenilenebilir enerji kaynaklarına yönlendirmektedir. Fotovoltaik paneller maliyetleri yüksek ve verimleri düşük olması sebebiyle verimlerinin artırılmasını, çalışmada önem arz etmektedir. Verim artırma amacıyla yapılan çalışmaların başarıya ulaşması hem maliyet hem de enerjinin verimli kullanılması açısından önem arz etmektedir. Günümüzde yapılan çalışmalardafotovoltaik panele göre maksimum \%47"ye varan verim artış1 gözlemlenmektedir. Bu konuda yapılacak çalışmaların ilerletilmesi ve olumlu sonuçlar alınması ile fotovoltaik panelden elektrik üretiminin daha da yaygınlaşması sağlanabilir. 


\section{Kaynaklar}

[1]K. Başaran, K., Çetin, N. S., Çelik, H., "Rüzgar-Güneş Hibrit Güç Sistemi Tasarımı ve Uygulamasi" 6. International Advanced Technologies Symposium (IATS'11), Sayfa 114-119, 2011.

[2] Zhijun P., Mohammad R. Herfatmanesh, Yiming L., "Cooled solar PV panels for output energy efficiency optimisation", Journal of Energy Conversion and Management, Vol.150, pp.949-955, 2017

[3]B. Kamanga, J. S. P. Mlatho, C. Mikeka, and C. Kamunda, "Optimum Tilt Angle for Photovoltaic Solar Panels in Zomba District, Malawi,” Journal of Solar Energy, vol. 2014, Article ID 132950, 9 pages, 2014.

[4] Arslan, K., Kurukavak A., Çalişma Akişkani Olarak Ag/Saf Su Nanoakişkani Kullanilan Bir Vakum Tüplü U-Borulu Güneş Kolektörünün Deneysel Olarak Incelenmesi, Yüksek lisans tezi, Karabük Üniversitesi, Karabük, Türkiye, 2019

[5] Çolak, S. Ç., "Fotovoltaik Paneller Yardımı İle Güneş Enerjisinden Elektrik Enrjisi Üretiminin Maliyet Analizi Ve Gelecekteki Projeksiyonu" Yıldız Teknik Üniversitesi Fen Bilimleri Enstitüsü Yüksek Lisans Tezi, 2010

[6] Abdoulatif Bonkaney, Saïdou Madougou, and Rabani Adamou, "Impacts of Cloud Cover and Dust on the Performance of Photovoltaic Module in Niamey," Journal of Renewable Energy, Vol. 2017, Article ID 9107502, 8 pages, 2017.

[7] Thomas, R., Fordham, M., 2001. Photovoltaics and Architecture, Spon Press, London and Newyork.

[8] R. Mazón-Hernández, J. R. García-Cascales, F. Vera-García, A. S. Káiser, and B. Zamora, "Improving the Electrical Parameters of a Photovoltaic Panel by Means of an Induced or Forced Air Stream," International Journal of Photoenergy, vol. 2013, Article ID 830968, 10 pages, 2013. 
[9] B. J. Brinkworth, B. M. Cross, R. H. Marshall, and H. Yang, "Thermal regulation of photovoltaic cladding," Solar Energy,vol. 61, no. 3, pp. 169-178, 1997.- For Journals

[10] K. V. Wong and O. De Leon, "Applications of nanofluids: current and future," Advances in Mechanical Engineering, vol. 2, Article ID 519659, 2010

[11] Lazaroiu Cristian George, Longo Michela, Roscia Mariacristina, Pagano Mario, (2015). "Comparative analysis of fixed and sun tracking low power PV systems considering energy consumption", Energy Conversion and Management, 92, pp.143-148

[12] R. Kamada, T. Yagoika, S. Adachi, A. Handa, K. Fai Tai, T. Kato, andH. Sugimoto, "New World Record Cu(In,Ga)(Se,S)2 Thin Film Solar Cell Efficiency Beyond 22\%," Proceedings of the 43th IEEE Photovoltaic Specialist Conference, pp. 1287-1291, 2016.

[13] T. Nakada, Y. Hirabayashi, T. Tokado, D. Ohmori, and T. Mise, "Novel device structure for $\mathrm{Cu}(\mathrm{In}, \mathrm{Ga}) \mathrm{Se} 2$ thin film solar cells using transparent conducting oxide back and front contacts," Solar Energy, vol. 77, no. 6, pp. 739-747, 2004.

[14] Green, Martin A., et al. "Solar cell efficiency tables (version 50)." Progress in Photovoltaics: Research and Applications 25.7 (2017): 668-676

[15] Rok Stropnik, Uroš Stritih, "Increasing the efficiency of PV panel with the use of PCM", "Journal of Renewable Energy", Vol.97, pp.671-679, 2016

[16] https://www.kontrolkalemi.com/forum/konu/g\%C3\%BCne\%C5\%9F-pilleri.117695/

[17] https://www.rfwireless-world.com/calculators/Solar-Cell-Efficiency-Calculator.html 